\title{
Reusability test of Silica-Titania Catalyst on Biodiesel Production from Waste Cooking Oil in Various Temperatures
}

\author{
Fiona Rachma Annisa ${ }^{1}$, Indang Dewata ${ }^{1}$, Hary Sanjaya ${ }^{1}$, Latisma Dj ${ }^{1}$, Ananda Putra ${ }^{1}$, Rita Sundari ${ }^{2}$, \\ Umar Kalmar Nizar ${ }^{*}$ \\ ${ }^{1}$ Chemistry Department, Universitas Negeri Padang, Jl. Prof Hamka, Air Tawar, Padang, West Sumatra, \\ Indonesia \\ ${ }^{2}$ Mechanical Engineering Department, Universitas Mercu Buana, Jakarta, Indonesia \\ *Email : umarjati77@gmail.com
}

\begin{abstract}
This work has investigated the reusability of silica-titania in various temperatures $\left(50-70^{\circ} \mathrm{C}\right)$ of biodiesel production from waste cooking oil. The reused silica-titania catalyst collected from silica-titania catalyst waste produced from the process of separating the catalyst from biodiesel products from palm oil and used cooking oil at various temperatures. The $1^{\text {st }}$ and $2^{\text {nd }}$ reused $\mathrm{SiO}_{2}-\mathrm{TiO}_{2}$ were characterized by $\mathrm{DR} \mathrm{UV}-\mathrm{Vis}$ and the spectra were deconvoluted for calculate the fraction of titanium in tetrahedral coordination. In addition the biodiesel products were characterized using FTIR, and several properties of biodiesel such as density, flow rate and acid value were analyzed in order to get the information about catalytic activity reused $\mathrm{SiO}_{2}-\mathrm{TiO}_{2}$. The results show the titanium tetrahedral fraction in reused catalyst (1st) and (2nd) are found to be $24,98 \%$ and $24.65 \%$, respectively. The FTIR characterization of biodiesel products and waste cooking oil are almost similar. The analysis of waste cooking oil converted to biodiesel shows an optimum temperature of $50^{\circ} \mathrm{C}$ that at this temperature the lowest density or highest flow rate gave highest conversion of $47.82 \%$ using BCR1 and $39.13 \%$ using BCR2.
\end{abstract}

Keywords : Biodiesel, Temperature, Reused Silica-Titania Catalyst, Properties of Biodiesel.

\section{INTRODUCTION}

The availability of diesel oil from fossil fuel has become limited generated serious problem in fuel need nowadays. High consumption of fossil fuel and limited availability in nature, as well as non renewable energy sources has caused world oil price continually increased [1]. On account of this, biodiesel as alternative fuel produced from vegetable oil can be applied to replace diesel from fossil fuel [2],
Waste cooking oil as one of vegetable oils is very potential as raw material for biodiesel production. The utilization of waste cooking oil for biodiesel production has saved waste discharge cost and maintenance. The free fatty acids (FFA) content in waste cooking oil can reduce environment quality around waste discharge. Therefore, waste cooking oil is a good choice as raw material to yield biodiesel [4] [3] 
The biodiesel can be produced through traansesterification reaction between triglycerides of vegetable oil and short chain alcohol using a given catalyst. Methanol as a short chain of alcohol member can be applied for biodiesel production due to its low molecular weight and stable compared to other member of alcohol [5]

The usage of a catalyst is substantial because transesterification reaction is a slow reaction. There are three groups of catalysts that is commonly used in transesterification reaction, i.e acid, base, and enzyme catalysts. The acid and base catalysts are grouped into homogeneous and heterogeneous catalysts.

The application of homogeneous catalyst for biodiesel production has several disadvantages such as soap formation as a by-product, less stable, tedious separation process of the product resulting less biodiesel production. In order to overcome the drawback a heterogeneous catalyst is preferred to overcome problems faced by homogeneous catalyst [6], [7].

Silica-titania $\left(\mathrm{SiO}_{2}-\mathrm{TiO}_{2}\right)$ as one of heterogeneous catalysts possesses large application in academic and industrial field. Several silica-titania catalysts are used for photocatalyst, catalyst, sensor materials, and others. The silica-titania catalyst has large active area, thermally stable, transparent, and can be used to overcome the weakness of titania catalyst [8], [9].

This research group has already conducted optimization of reaction temperature using silicatitania catalyst in biodiesel production from palm and waste cooking oils. The highest percentage of conversion achieved $33.33 \%$ using palm oil at $65^{\circ} \mathrm{C}$ and $57.1 \%$ using waste cooking oil at $55^{\circ} \mathrm{C}$. Based on data mentioned above silica-titania catalyst with its acid properties is effective for reaction of waste cooking oil with high content of FFA [10]

This work has emphasized on the variation of temperature in biodiesel production from waste cooking oil applied re-used silica-titania catalyst by examinations on percentage of FFA and conversion, as well as properties of biodiesel products. This study has used silica-titania catalyst synthesized by a solid state method and waste cooking oil as reactant.

\section{METHODS AND MATERIAL}

\subsection{Materials and devices}

The materials are classified into materials for catalyst preparation and biodiesel production. The reused silica-titania catalyst was obtained by washing the catalyst used in the previous reaction. The solvens used for catalyst preparation were hexane and methanol. The biodiesel production needed waste cooking oil, methanol, ethanol, $\mathrm{KOH}$, and pp indicator [9].

\subsection{Equipments}

The equipments used in this study included equipment for synthesis and characterization. For synthesis, this study needed glassware, hot plate stirrer, oven, balance, thermometer, stirrer, centrifuge and fume hood. Instrument used for characterization of silica-titania catalyst was DR UVVis spectrometer while the biodiesel product was characterized by FTIR spectrometer.

\subsection{Preparation and charaterization of reused silica- titania catalyst}

The reused silica-titania catalyst is originally the freshly prepared silica-titania catalyst that reapplied for next experiment denoted as " 1 st re-used" after once washing and applied again, and denoted as " $2^{\text {nd }}$ 
re-used" after twice washing and applied again for next experiment. The re-used silica-titania catalyst was obtained by three time washing with $25 \mathrm{~mL} \mathrm{n}$ hexane and dried at room temperatur, and then washed by methanol, remained in a fumehood for a night to evaporate methanol. Furthermore, the given catalyst was dried in an oven for $2 \mathrm{~h}$ at $105^{\circ} \mathrm{C}$. After that, the given catalyst was cooled in a desiccant and followed by DR UV-Vis characterization in the wavelength range of $200-400 \mathrm{~nm}^{-1}$ [11], [12]

Afterwards, the given catalyst was applied again in reaction of waste cooking oil to yield biodiesel. After the transesterification reaction finished, the given catalyst was separated and prepared again following the procedure as already mentioned above for the next transesterification reaction.

\subsection{Application of re-used silica-titania catalyst.}

The given catalyst after preparation was applied again for biodiesel production from waste cooking oil and methanol. The transesterification conducted in various temperatures of $50-70^{\circ} \mathrm{C}$ for $5 \mathrm{~h}$ and catalyst loading of $7 \%$ with mol ratio of methanol to waste cooking oil of 6:1 [9].

Then the mixture was cooled after the reaction finished and followed by further process, i.e the separation of catalyst using a centrifuge. Further separation was done to remove excess methanol by heating above boiling point of methanol $\left(64.7^{\circ} \mathrm{C}\right)[13]$.

\subsection{Catalytic activity}

The catalytic activity can be examined by assignment or analysis the biodiesel products through several tests for density, flow rate, acid number, and conversion, as well as FTIR characterization at wave number range of $600-4000 \mathrm{~cm}^{-1}$. Table 1 show sample labeling used in this study.
Table 1: Labels of biodiesel products from waste cooking oil (WCO) applying re-used silicatitania catalyst.

\begin{tabular}{cccc}
\hline \multicolumn{4}{c}{ Labels of biodiesel products } \\
\hline \multicolumn{3}{c}{$1^{\text {st }}$ reusability } & \multicolumn{3}{c}{$2^{\text {nd }}$ reusability } \\
\hline $\begin{array}{c}\text { Temperatur } \\
\text { e }\left({ }^{\circ} \mathrm{C}\right)\end{array}$ & Label & $\begin{array}{c}\text { Temperatur } \\
\text { e }\left({ }^{\circ} \mathrm{C}\right)\end{array}$ & Label \\
\hline $50^{\circ} \mathrm{C}$ & BCR1-50 & $50^{\circ} \mathrm{C}$ & BCR2-50 \\
$55^{\circ} \mathrm{C}$ & BCR1-55 & $55^{\circ} \mathrm{C}$ & BCR2-55 \\
$60^{\circ} \mathrm{C}$ & BCR1-60 & $60^{\circ} \mathrm{C}$ & BCR2-60 \\
$65^{\circ} \mathrm{C}$ & BCR1-65 & $65^{\circ} \mathrm{C}$ & BCR2-65 \\
$70^{\circ} \mathrm{C}$ & BCR1-70 & $70^{\circ} \mathrm{C}$ & BCR2-70 \\
\hline
\end{tabular}

\section{III.RESULTS AND DISCUSSION}

\subsection{DR UV-Vis spectra of re-used silica-titania catalyst (re-used $1^{\text {st }}$ and $2^{\text {nd }}$ )}

Re-used catalyst has to show good stability, otherwise, loss of stability affects the catalyst performance and reduces its catalytic action. Therefore, an examination by DR UV-Vis is important to determine its titanium tetrahedral fraction in re-used silicatitania catalyst and compared to that of previous silica-titania catalyst. The deconvolution spectra of DR UV-Vis of re-used silica-titania catalyst ( $1^{\text {st }}$ and $2^{\text {nd) }}$ are illustrated in Figure 1 and Figure 2

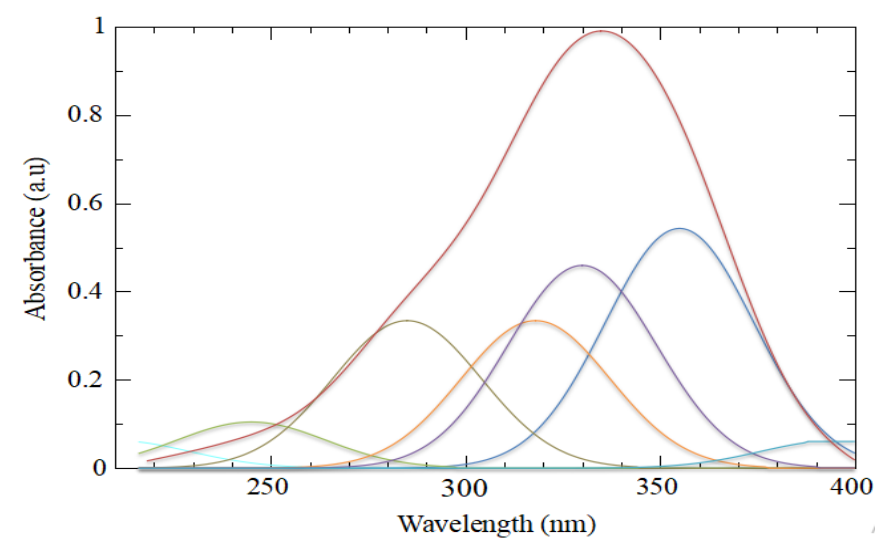

Figure 1: Deconvolution spectra of DR UV-Vis of reused silica-titania $\left(1^{\text {st }}\right)$ 


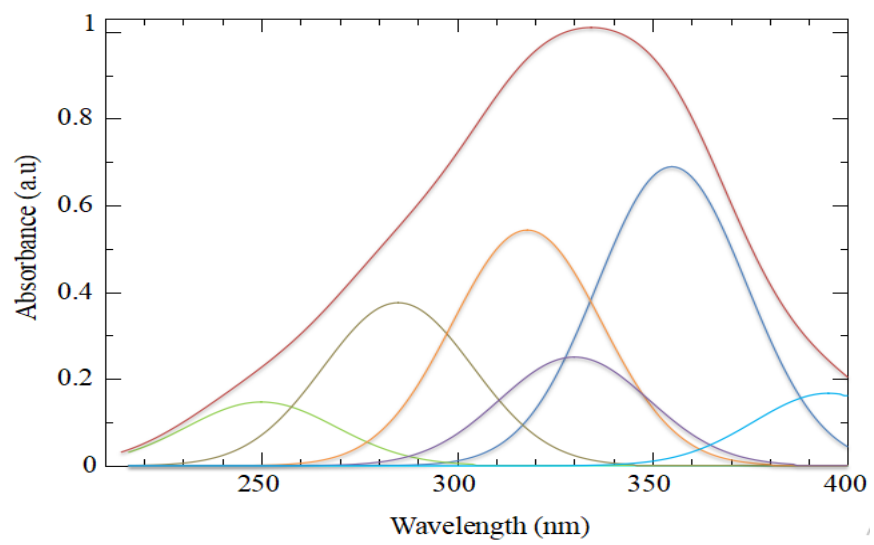

Figure 2: Deconvolution spectra of DR UV-Vis of reused silica-titania $\left(2^{\text {nd }}\right)$

Based on the deconvolution spectra of DR UV-Vis of re-used silica-titania (1 $\left.{ }^{\text {st}}\right)$ shown in Fig.1 and reused silica-titania $\left(2^{\text {nd }}\right)$ shown in Fig. 2, the results with respect to titanium tetrahedral coordination are found to be $24,98 \%$ and $24,65 \%$, respectively. There is a reduction of titanium tetrahedral coordination as compared to that of previous silica-titania catalyst (31.04\%) [14]

Nevertheless, the content of titanium tetrahedral coordination of re-used catalysts ( $1^{\text {st }}$ and $\left.2^{\text {nd }}\right)$ are still higher than that of commercial $\mathrm{TiO}_{2}$ (23\%). This is probably corresponding with stability of $\mathrm{Si}-\mathrm{O}-\mathrm{Ti}$ bonding over temperature and time during the course of transesterification reaction. The stability of $\mathrm{Si}-\mathrm{O}-\mathrm{Ti}$ affected its catalytic action causing a reduction in percentage of conversion to biodiesel production [9]

Besides, it is also affected by phase transformation of anatase to rutile attributed to reduction of absorption peak of titanium tetrahedral coordination below 270 $\mathrm{nm}$ at deconvolution spectra of DR UV-Vis of re-used silica-titania catalyst. During the transesterification reaction, there was a destruction of $\mathrm{Si}-\mathrm{O}-\mathrm{Ti}$ bonding in some parts of catalyst molecule yielding formation of $\mathrm{Si}-\mathrm{O}-\mathrm{Si}$ and $\mathrm{Ti}-\mathrm{O}-\mathrm{Ti}$ bonding related to formation of less active titanium octahedral coordination. The structure of Ti-O-Ti can be found in both phases of anatase and rutile. In the wavelength range of 280-
$300 \mathrm{~nm}$ the active anatase phase is more dominant, on the other hand, in the wavelength range of 330$400 \mathrm{~nm}$ the less active rutile phase is more remarkable [9]

\subsection{FTIR spectra of biodiesel products.}

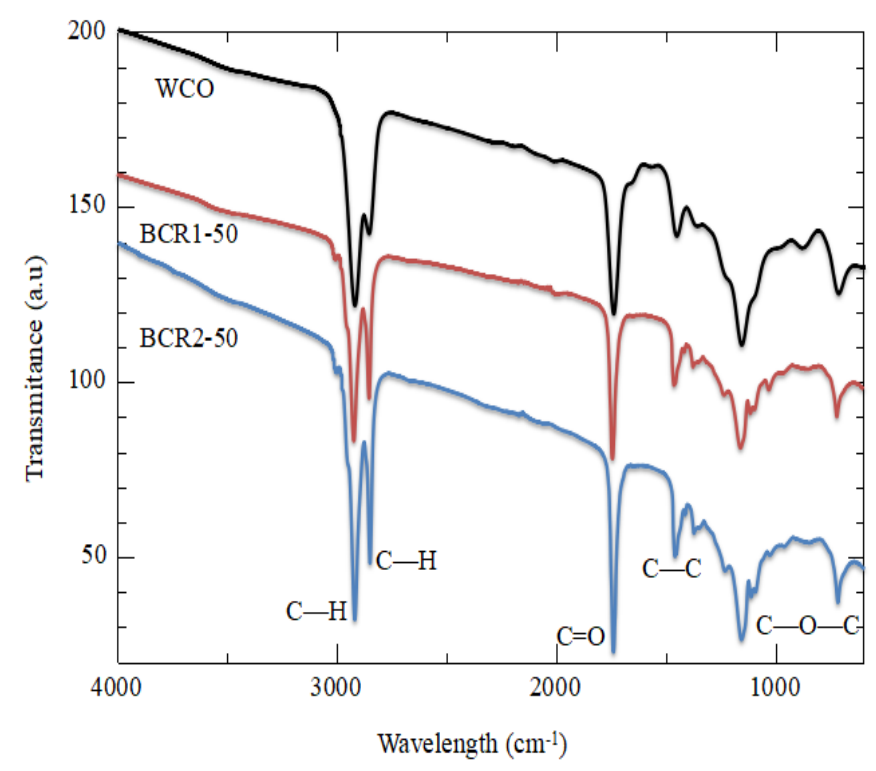

Figure 3: FTIR spectra of biodiesel products at optimum temperature $\left(50^{\circ} \mathrm{C}\right)$.

The FTIR characterization of biodiesel products is based on the best results obtained from examination of biodiesel properties. The absorption peak at wave number of vibration $\left(1300-1000 \mathrm{~cm}^{-1}\right)$ is the main absorption peak of waste cooking oil and biodiesel products $\left(50^{\circ} \mathrm{C}\right)$. At this area, there is an absorption peak of $\mathrm{C}-\mathrm{O}$ ester from triglycerides and $\mathrm{C}-\mathrm{O}$ from carboxyl fatty acid (Figure 3). The absorption peak of biodiesel is wider than that of waste cooikng oil in the range of $1300-1000 \mathrm{~cm}^{-1}$. Several other absorption peaks at wave number of $1744 \mathrm{~cm}^{-1}$ attributed to vibration of $\mathrm{C}=\mathrm{O}$ bonding from ester, while a weak absorption peak at wave number $2922 \mathrm{~cm}^{-1}$ attributed to $-\mathrm{CH} 2$.

Other main absorption peak at $1463 \mathrm{~cm}^{-1}$ attributed to methyl ester group ( $\mathrm{CO}-\mathrm{O}-\mathrm{CH})$ and strengthened by an absorption peak of ester $(\mathrm{C}-\mathrm{O})$ at wave number of $1116 \mathrm{~cm}^{-1}$. There is a little difference of FTIR spectra between biodiesel and waste cooking oil due 
to different chemical bonding in biodiesel and waste cooking oil.

Table 2: Significant absorption peaks of waste cooking oil (WCO) and biodiesel products

\begin{tabular}{cccc}
$\begin{array}{c}\text { Type } \\
\text { of } \\
\text { bond }\end{array}$ & $\begin{array}{c}\text { WCO } \\
\text { absorption } \\
\text { wave number } \\
\left(\mathrm{cm}^{-1}\right)\end{array}$ & $\begin{array}{c}\text { BCR1-50 } \\
\text { absorption } \\
\text { wave } \\
\text { number }\left(\mathrm{cm}^{-}\right. \\
1)\end{array}$ & $\begin{array}{c}\text { BCR2-50 } \\
\text { absorption } \\
\text { wave }\end{array}$ \\
$\begin{array}{cccc}\text { number }\left(\mathrm{cm}^{-}\right. \\
\text {C=O }\end{array}$ & 1742,81 & 1744.26 & 1744,16 \\
C-H & 2922,27 & 2922,70 & 2922,67 \\
C-C & 1455,67 & 1463,93 & 1463,90 \\
C-O- & 1159,53 & 1463,93 & 1116.67 \\
C & & & \\
\hline
\end{tabular}

The data in Table 2 shows similarity in remarkable absorption peaks between waste cooking oil and biodiesel products. The similarity in absorption spectra between WCO and biodiesel is due to similar structure of functional group of triglycerides and methyl ester. The little difference between FTIR spectra of WCO and biodiesel is due difference in chemical bonding found on those chemical compounds.

\subsection{Properties of biodiesel products}

3.3.1. Density and Viscosity (Flow rate)

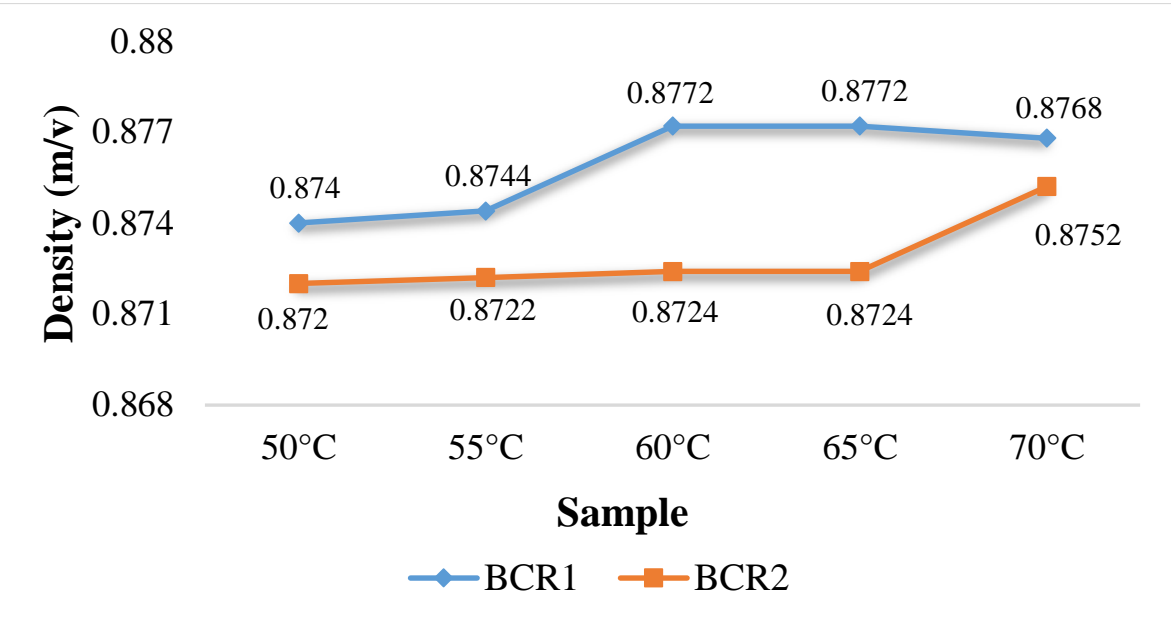

Figure 4: Density of biodiesel products at varied temperatures.

Figure 4 shows the density of biodiesel products at optimum temperature $\left(50^{\circ} \mathrm{C}\right)$ applying re-used silicatitania catalyst $\left(1^{\text {st }}\right.$ and $2^{\text {nd }}$ ) that were found lower than that of WCO. The density values of biodiesel products $\left(50^{\circ} \mathrm{C}\right)$, i.e. $0.874 \mathrm{~g} / \mathrm{mL}$ (BCR1-50) and 0.872 $\mathrm{g} / \mathrm{mL}$ (BCR2-50), that are lower than that of WCO $(0.879 \mathrm{~g} / \mathrm{mL})$ and then increased again at $70^{\circ}$. The elevation of density values is proportional with elevation of temperature in relation to glycerol content in biodiesel products and WCO. The incomplete separation of glycerol from biodiesel yielded glycerol residue in biodiesel and strongly affected the density value [15]

The flow rate test can present the viscosity of fluids, which the flow rate is inversely proportional to viscosity, or in other words, the higher flow rate reflected the lower viscosity. Fig. 5 shows the flow rates of BCR1-50 and BCR2-50 at optimum temperature $\left(50^{\circ} \mathrm{C}\right)$, i.e. $0.505 \mathrm{~mL} / \mathrm{s}$ and $0.434 \mathrm{~mL} / \mathrm{s}$, respectively, that are higher than that of WCO $(0.421$ $\mathrm{mL} / \mathrm{s})$.

The temperature strongly affected the biodiesel production. Reduced temperature yielded lower flow 
rate or higher viscosity, because the reaction is not too effective at low temperature. When the temperature is getting increased yielding increased reaction product due to much more energy supply.
However, when the temperature is too high resulting not effective reaction due to alcohol vaporized and probably soap formation [16]

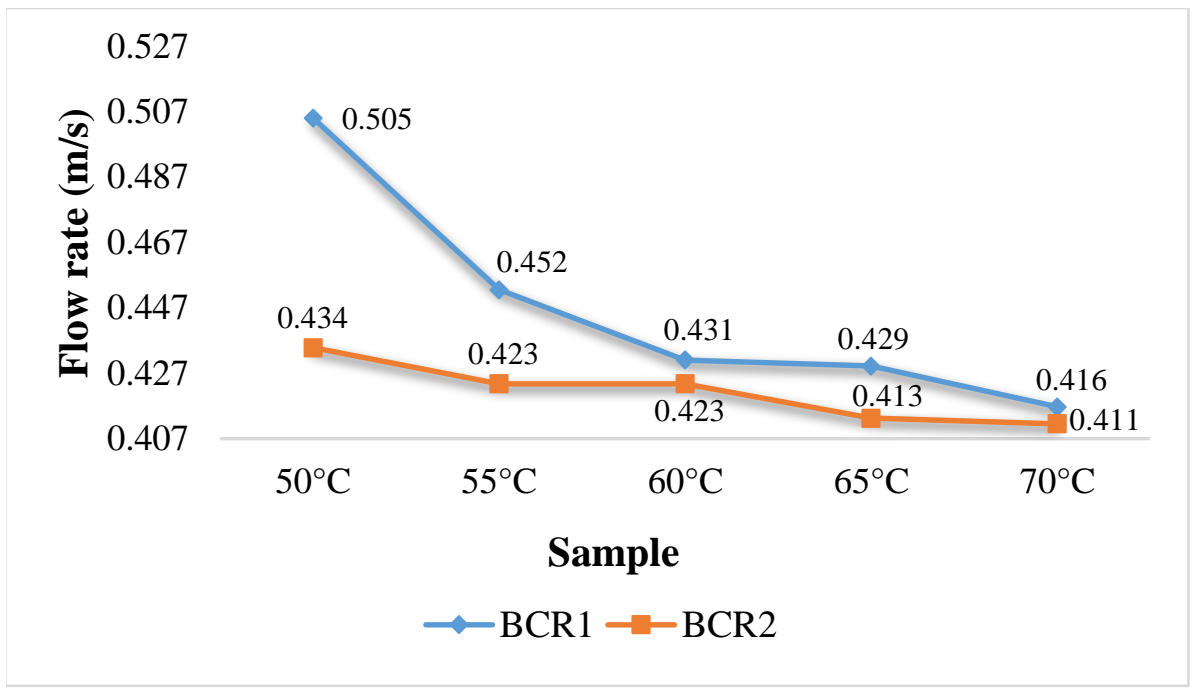

Figure.5: Flow rate of biodiesel products at varied temperatures

\subsubsection{Acid number}

The assignment of acid number is to determine the FFA content in biodiesel products. The acid number is determined by acid - base titration method. The results of biodiesel conversion show that silica-titania catalyst is effective for WCO with high \% FFA.

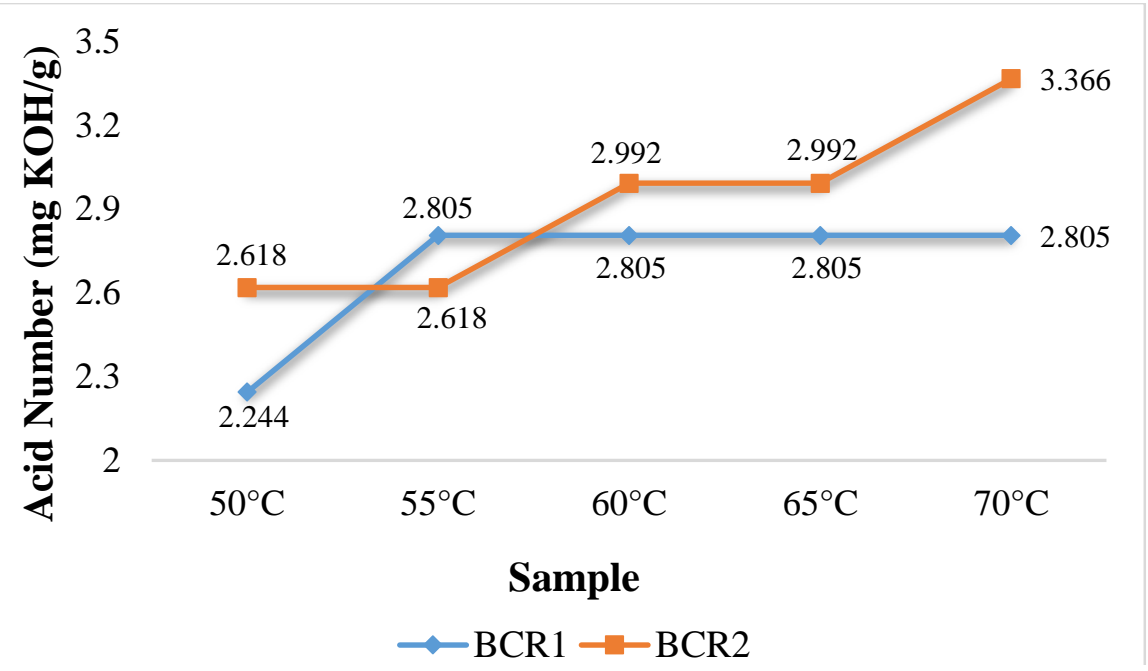

Figure 6: Acid number of biodiesel products

Figure 6 shows the acid number of biodiesel products and they are found to be lower than that of WCO (4.301 mg KOH/g) expressed in Table 3. The data of acid number can be used to determine the $\%$ FFA and percentage of conversion of WCO to biodiesel products as seen in Table 4 
Table 3: Acid number, \% FFA, and \% conversion applying re-used catalyst (BCR1)

\begin{tabular}{cccc}
\hline Sample & Acid number & \% FFA & \% Conversion \\
\hline $\mathrm{WCO}$ & 4.301 & 2.1505 & \\
$50^{\circ} \mathrm{C}$ & 2.244 & 1.122 & $47.82 \%$ \\
$55^{\circ} \mathrm{C}$ & 2.805 & 1.4025 & $34.78 \%$ \\
$60^{\circ} \mathrm{C}$ & 2.805 & 1.4025 & $34.78 \%$ \\
$65^{\circ} \mathrm{C}$ & 2.805 & 1.4025 & $34.78 \%$ \\
$70^{\circ} \mathrm{C}$ & 2.805 & 1.4025 & $34.78 \%$ \\
\hline
\end{tabular}

Table 4: Acid number, \% FFA, and \% conversion applying re-used catalyst (BCR2)

\begin{tabular}{cccc}
\hline Sample & Acid number & \% FFA & \% Conversion \\
\hline WCO & 4.301 & 2.1505 & \\
$50^{\circ} \mathrm{C}$ & 2.618 & 1.309 & $39.13 \%$ \\
$55^{\circ} \mathrm{C}$ & 2.618 & 1.309 & $39.13 \%$ \\
$60^{\circ} \mathrm{C}$ & 2.992 & 1.496 & $30.43 \%$ \\
$65^{\circ} \mathrm{C}$ & 2.992 & 1.496 & $30.43 \%$ \\
$70^{\circ} \mathrm{C}$ & 3.366 & 1.683 & $21.73 \%$ \\
\hline
\end{tabular}

Table 3 and Table 4 show that \%FFA of biodiesel products are lower than that of WCO. The FFA content in the reactant like oil sources is substantial because it affects the reaction conversion. The high content of FFA has tendency for soap formation that in turn it reduced biodiesel product, because soap can hinder separation and purification process. More number of repeating the usage of silica-titania catalyst may decrease the conversion of vegetable oil to biodiesel.

The percentage of conversion to yield BCR1-50 and BCR2-50 are found to be $47.82 \%$ and $39.13 \%$, respectively. This finding shows a reduction in catalytic action that is corresponding with reduction of titanium tetrahedral coordination and washing of catalyst due to repeatable usage of catalyst.

The examination of properties of biodiesel shows that silica-titania catalyst is reusable although its catalytic action decreased. Nevertheless, the application of re- used silica-titania catalyst is still effective at optimum temperature $\left(50^{\circ} \mathrm{C}\right)$ justified from increased flow rate and decreased density, as well as lower acid number of biodiesel products compared to that of WCO.

\section{IV.CONCLUSION}

The titanium tetrahedral coordination in silica-titania catalyst decreased after repeat usage of the given catalyst in biodiesel production from WCO. The optimum temperature in this study was found to be $50^{\circ} \mathrm{C}$ for respective production of $\mathrm{BCR} 1-50$ and BCR2-50.

\section{ACKNOWLEDGMENTS}

The author(s) would like to thank and express deepest gratitude to the Directorate of Research and Community Service of Universitas Negeri Padang, for their assistance in Research Funding, and also to Chemical Laboratory, Chemistry department, Faculty of Mathematic and Natural Science, Universitas Negeri Padang for supports and facilitations.

\section{REFERENCES}

[1]. I. M. Lokman, U. Rashid, and Y. H. Taufiq-Yap, "Meso- and macroporous sulfonated starch solid acid catalyst for esterification of palm fatty acid distillate," Arab. J. Chem., vol. 9, no. 2, pp. 179189, 2016.

[2]. A. Hidayat, Rochmadi, K. Wijaya, A. Nurdiawati, W. Kurniawan, H. Hinode, K. Yoshikawa, and A. Budiman, "Esterification of Palm Fatty Acid Distillate with High Amount of Free Fatty Acids Using Coconut Shell Char Based Catalyst," Energy Procedia, vol. 75, pp. 969-974, 2015.

[3]. I. Istadi, D. D. Anggoro, L. Buchori, D. A. Rahmawati, and D. Intaningrum, "Active Acid Catalyst of Sulphated Zinc Oxide for Transesterification of Soybean Oil with Methanol 
to Biodiesel," Procedia Environ. Sci., vol. 23, no. Ictcred 2014, pp. 385-393, 2015.

[4]. J. F. García-Martín, C. C. Barrios, F. J. AlésÁlvarez, A. Dominguez-Sáez, and P. AlvarezMateos, "Biodiesel production from waste cooking oil in an oscillatory flow reactor. Performance as a fuel on a TDI diesel engine," Renew. Energy, vol. 125, pp. 546-556, 2018.

[5]. V. Rathore, B. L. Newalkar, and R. P. Badoni, "Processing of vegetable oil for biofuel production through conventional and non-conventional routes," Energy Sustain. Dev., vol. 31, pp. 24-49, 2016.

[6]. L. H. Firdaus, A. R. Wicaksono, and Widayat, "Pembuatan katalis h-zeolit dengan impregnasi ki/kio 3 dan uji kinerja katalis untuk produksi biodiesel," Teknol. Kim. dan Ind., vol. 2, no. 2, pp. 148-154, 2013.

[7]. N. S. Talha and S. Sulaiman, "OVERVIEW OF CATALYSTS IN BIODIESEL PRODUCTION," vol. 11, no. 1, pp. 439-448, 2016.

[8]. N. Sootchiewcharn, L. Attanatho, and P. Reubroycharoen, Biodiesel Production from Refined Palm Oil using Supercritical Ethyl Acetate in A Microreactor, vol. 79. Elsevier B.V., 2015.

[9]. U. K. Nizar, J. Hidayatul, R. Sundari, B. Bahrizal, A. Amran, A. Putra, L. Latisma Dj, and I. Dewata, "The Effect of Titanium Tetrahedral Coordination of Silica-Titania Catalyst on the Physical Properties of Biodiesel," IOP Conf. Ser. Mater. Sci. Eng., vol. 335, no. 1, 2018.

[10]. T. P. Raffeza, A. Putra, L. Dj, B. Oktavia, D. Kurniawati, S. B. Etika, R. Sundari, and U. K. Nizar, "The Role of Temperature on Biodiesel Production from Palm and Waste Cooking Oils Catalyzed By Silica-Titania Catalyst," pp. 152156, 2019.

[11]. S. Alaei, M. Haghighi, J. Toghiani, and B. Rahmani, "Industrial Crops \& Products Magnetic and reusable $\mathrm{MgO} / \mathrm{MgFe} 2 \mathrm{O} 4$ nanocatalyst for biodiesel production from sun $\mathrm{fl}$ ower oil: In fl uence of fuel ratio in combustion synthesis on catalytic properties and performance," Ind. Crop. Prod., vol. 117, no. September 2017, pp. 322-332, 2018.

[12]. J. Dantas, E. Leal, D. R. Cornejo, and A. C. F. M. Costa, "Biodiesel Production Evaluating the Use and Reuse of Magnetic Nanocatalysts Ni0.5Zn0.5Fe2O4," Arab. J. Chem., 2018.

[13]. U. K. Nizar, J. Efendi, L. Yuliati, D. Gustiono, and H. Nur, "A new way to control the coordination of titanium (IV) in the sol-gel synthesis of broom fibers-like mesoporous alkyl silica-titania catalyst through addition of water," Chem. Eng. J., vol. 222, pp. 23-31, 2013.

[14]. Z. Zurryati, R. Sundari, B. Bahrizal, A. Putra, L. DJ, E. Nasra, D. Kurniawati, and U. K. Nizar, "The Effect of Silica-Titania Catalyst Loading on the Production of Biodiesel from Palm and Waste Cooking Oil Abstract :," Int. J. Sci. Res. Eng. Dev., vol. 2, no. 3, pp. 96-101, 2019.

[15].D. Teknik, "Pengaruh suhu dalam proses transesterifikasi pada pembuatan biodiesel kemiri sunan," vol. 7, no. 1, pp. 9-18, 2017.

[16]. A. Bilgin, M. Gülüm, İ. Koyuncuoglu, E. Nac, and A. Cakmak, "Determination of transesterification reaction parameters giving the lowest viscosity waste cooking oil biodiesel," vol. 195, pp. 24922500, 2015.

Cite this article as : Fiona Rachma Annisa, Indang Dewata, Hary Sanjaya, Latisma Dj, Ananda Putra, Rita Sundari,Umar Kalmar Nizar , "Reusability test of Silica - Titania Catalyst on Biodiesel Production from Waste Cooking Oil in Various Temperatures", International Journal of Scientific Research in Science and Technology (IJSRST), Online ISSN : 2395-602X, Print ISSN : 2395-6011, Volume 6 Issue 4, pp. 116-123, July-August 2019. Available at doi : https://doi.org/10.32628/IJSRST196414 Journal URL : http://ijsrst.com/IJSRST196414 